YAK 347.45/.47

DOI https://doi.org/10.32837/chc.v0i43.441

\author{
Войчишин Олексій Валентинович, \\ аспірант \\ Навчально-наукового інституту права імені І. Малиновського \\ Національного університету "Острозька академія" \\ ORCID ID: 0000-0003-0612-1383
}

\title{
ДО ПИТАННЯ ПРО ПРАВОВУ ПРИРОДУ КОРПОРАТИВНОГО ДОГОВОРУ
}

Натепер у законодавстві, зокрема в законах України "Про товариства з обмеженою та додатковою віАповідальністю" та "Про акціонерні товариства", закріплені Аефініції корпоративного Аоговору Аля товариств з обмеженою та Аодатковою віАповіАальністю, акціонерних товариств. Проте правова природа договору не може бути розкрита лише крізь призму його визначення. Розкриття правової природи сприяє правильному тлумаченню Аоговору, його посліАовній правозастосовній практиці.

АосліАження правової природи корпоративного Аоговору вже було преАметом наукових праць В.В. Васильєвої, К.О. Рябової, М.М. СигиАин, О.В. Бігняк. ОАнак у зв'язку з появою нового законодавчого регулювання щоАо корпоративного Аоговору $€$ необхіАність у переосмисленні його правової природи.

Таке поняття, як "правова природа", часто вживається науковцями, однак немає єАиного піАходу Ао його визначення. Зокрема, піА поняттям "правова природа" може розумітись як вичерпна характеристика юридичного явища, визначення правової природи означає встановлення місця юридичного факту в системі права шляхом розкриття істотних специфічних ознак. ВіАповіАно Ао іншого піАхоАу, пізнати правову природу - розкрити функції та наАати правову характеристику [6].

Отже, завАанням статі $€$ розкриття правової природи корпоративного Аоговору шляхом визначення його ознак, функцій, установлення місця корпоративного Аоговору в системі Аоговорів.

Так, В.В. Васильєва Ао ознак такого правочину, як корпоративний Аоговір, відносить: вольо- вий характер, наявність сторін, їхню незалежність та волевиявлення, направленість волі сторін на виникнення або зміну прав і обов'язків, Аомовленість сторін, законну форму волевиявлення, правомірність Аій, віАображення Аинаміки віАносин між сторонами, спрямованість на настання правових наслідків [3, с. 56].

Запропоновані вченою ознаки характеризують корпоративний Аоговір з погляАУ Аоговірного акта. Проте завАаннями ознак $€$ також виявлення й ілюстрування різниці свого носія віА подібних явищ. Тому Аоцільно буде навести ознаки корпоративного Аоговору.

А^я корпоративного Аоговору такими ознаками є його преАмет [3, с. 57] і акцесорність його зобов'язань [12].

Найчастіше Аоговори віАмежовуються оАин віА оАного саме на піАставі преАмету Аоговору. В.В. Васильєва, М.М. СигиАин також уважають, що преАмет корпоративного Аоговору $€$ тією ознакою, яка Аозволяє відмежувати корпоративний Аоговір віА інших Аоговорів. ВіАповіАно Ао Закону України "Про акціонерні товариства" (Аалі - Закон "Про АТ") та Закону України "Про товариства з обмеженою та додатковою відповіАальністю" (Аалі - Закон "Про ТОВ"), преАметом корпоративного Аоговору Аля таких організаційно-правових форм $\epsilon$ реалізація (утримання віА реалізації) їх учасниками своїх корпоративних прав. Продовженням цієї ознаки можна видімити і таки похіАні ознаки, як: обтяженість корпоративним елементом [2], специфічний склаА сторін корпоративного Аоговору. Специфічний склаА сторін корпоративного Аоговору зумовлений тим, що лише учасники акціонерного товари- 
ства або товариства з обмеженою відповідальністю $є$ носіями прав, що виступають предметом такого Аоговору.

Іншою характерною ознакою корпоративного Аоговору, що віАрізняє його віА інших Аоговорів, $€$ акцесорність корпоративного Аоговору щодо юридичної особи, порядок реалізації корпоративних прав якої він урегульовує, та її статуту.

Така ознака, як акцесорність, Аозволяє вирішити низку практичних питань. По-перше, вона Аозволяє Аиференціювати корпоративний Аоговір віА статуту компанії. Корпоративний Аоговір не може змінювати статут компанії, не може йому суперечити з огляду на різні преАмети регумювання.

Саме акцесорність корпоративного Аоговору Аозволяє розмежувати корпоративний Аоговір та інші Аоговори щодо акціонерних товариств і товариств з обмеженою відповідальністю. Пропонуємо розглянути приклаА із засновницьким Аоговором. ЗгіАно із Цивільним кодексом України установчим Аокументом юридичної особи може бути засновницький Аоговір, якщо інше не встановлено законом [13]. Закон "Про ТОВ" також передбачає, що Аоговір про створення товариства Аіє Ао Аня Аержавної реєстрації товариства, якщо інше не встановлено договором або не випливає із суті зобов'язання [11]. Проте Закон "Про АТ", хоча і передбачає можливість укладення засновницького Аоговору, однак не Аозволяє йому піАміняти установчі Аокументи [10]. Отже, засновницький Аоговір, на віАміну віА корпоративного Аоговору, може бути установчим Аокументом, у такому Аоговорі можуть встановлюватись права учасників такої юридичної особи.

Істотним у контексті розуміння природи корпоративного Аоговору є визначення його функцій Аля того, щоб розуміти, яким чином зАійснюється його вплив на суспільні віАносини.

Учений О.А. Красавчиков уважає, що функція Аоговору є видом впливу певного явища на суспільні віАносини [8, с. 16]. Основні цілі, призначення Аоговору розкриваються через функції Аоговору [5, с. 68].

Аоговори виконують такі основні функції: гарантійну, регулятивну й охоронну. Ао Аругорядних функцій Аоговору можна віднести ініціативну, програмно-координаційну, інформаційну та гарантійну функції [5, с. 68]. Усі вищевказані функції притаманні і корпоративному Аоговору як Аоговірній конструкції.

Пропонуємо виАілити такі специфічні Аля корпоративного Аоговору функції, як:
1. Майнова функція. Аоговір може впливати на підстави набуття, зміни або втрати майнових прав учасниками, акціонерами. Законодавство Аозволяє врегульовувати в корпоративному Аоговорі умови або порядок визначення умов, на яких учасник має право або зобов'язаний купити або продати частку у статутному капіталі (ії частину), а також визначати випадки, коли таке право або обов'язок виникає [11].

Корпоративний Аоговір не $€$ підставою Аля переходу права власності на частку, однак може виступати важливою передумовою переходу майнових прав.

2. Управлінська функція. Учасники товариства, визначаючи у корпоративному Аоговорі порядок реалізації деяких своїх прав (наприклаА, порядок голосування щодо обрання виконавчого органу), впливають і на управління товариства. На думку А.С. Щегуренкова [14], к^ючовою функцією корпоративного Аоговору $є$ саме зАійснення корпоративного управління.

3. Функція контролю. Учасники, що уклали корпоративний Аоговір, матимуть інструменти Аля зАійснення контролю за Аіяльністю органів управління й інших учасників, акціонерів, що теж $є$ сторонами Аоговору. Аодатковим важелем контролю може слугувати безвідклична Аовіреність із корпоративних прав (у разі ії надання) як інструмент контролю виконання іншими сторонами Аоговору своїх зобов'язань.

4. Прогностична функція. Суть цієї функції звоАиться Ао того, що положення корпоративного Аоговору можуть передбачати певний поряАок Аій у майбутньому. Зокрема, корпоративний Аоговір може містити положення про порядок розгляАу ситуацій, щодо яких учасники не Аійшли згоди (“Deadlcok resolution clause"), або впорядкувати віАносини між міноритаріями та мажоритаріями, визначити специфічні умови продажу їхніх часток, акцій.

Отже, окрім загальних функцій корпоративного Аоговору як Аоговірної конструкції, йому притаманні специфічні функції, які дуже тісно пов'язані із предметом цього Аоговору.

Незважаючи на те, що однією з ознак системи Аоговорів є їі єАність та взаємопов'язаність, іiі також можна Аиференціювати (класифікувати в середині) за певними ознаками. Класифікація Аоговорів має не мише пізнавальний характер, а й велике практичне значення - допомагає краще пізнати зміст та правову природу, іАентифікувати місце корпоративного Аоговору в системі суспільно-правових віАносин [9, с. 55]. 
С.М. Барвено вважає, що систематизація Аоговорів $€$ важливою Аля вАосконалення чинного законодавства та піАготовки законопроєктів [5, с. 322].

Є різні підходи Ао класифікації системи Аоговорів. Ключові Ава піАходи [9, с. 336] Ао поділу Аоговорів: одноступенева та багатоступенева класифікації.

В основу одноступеневої класифікації поклаАено поді^ АОГоворів За оАним ЄАиним Критерієм. На жаль, у Аоктрині немає загального підходу щодо єАиного універсального критерію. Це видається ^огічним, зважаючи на всю різноманітність Аоговорів. У зв'язку із цим пропонуємо більш Аетально зупинитись на багатоступеневій (Аихотомічна) класифікації, використати саме ії Аля характеристики корпоративного договору.

На противагу оАноступеневій класифікації, Аихотомічний піАхіА базується на використанні декількох критеріїв. Найчастіше використовують такі Аихотомічні мірила [5, с. 340-342; 1, с. 69-72]:

1) особливості волевиявлення сторін на уклаАення Аоговору - вільні й обов'язкові.

Сторони корпоративного Аоговору самостійно ухвалюють рішення вступати чи не вступати в такі Аоговірні відносини. Тому корпоративний Аоговір можна схарактеризувати як вільний;

2) ступінь нормативного регулювання - поіменовані та непоіменовані. Корпоративний договір варто віднести Ао категорії поіменованих Аоговорів, оскільки він прямо закріплений у законодавстві - у Законі "Про ТОВ" та Законі "Про АТ";

3) особливості волі сторін щодо визначення умов Аоговору - Аоговори приєАнання та взаємопогоджені Аоговори. Сторони корпоративного Аоговору самостійно і спільно визначають умови корпоративного Аоговору у процесі переговорів. Як насліАок, Аоговір може вважатись взаємопогоАженим.

Іноді корпоративний Аоговір може виступати Аоговором приєАнання. НаприклаА у ситуації, коли корпоративний Аоговір містить положення про обов'язкове приєАнання Ао Аоговору нового учасника товариства;

4) залежно віА Аіяльності, що $є$ предметом Аоговору, - майнові й організаційні. Корпоративний Аоговір має на меті спільне управління учасниками й іншими сторонами юридичної особи. Отже, Аоговір можна віАнести до організаційних Аоговорів;

5) залежно віА розподілу Аоговірних прав і обов'язків - односторонні та Авосторонні. Поря-
Аок реалізації прав і обов'язків учасників, який $€$ предметом корпоративного договору, зумовлює спільну Аіяльність учасників та, як наслідок, їхніх взаємних прав і обов'язків. у зв'язку із цим корпоративні договори мають переважно Авосторонній характер.

3 іншого боку, не можна виключати, що за Аеяких умов корпоративний договір може мати і односторонній характер. Як-от у разі, коли одна сторона зобов'язується мише придбати частку у статутному капіталі за певних умов, а інша сторона має лише обов'язок продати ії. Проте односторонність Аоговору не повинна впливати на загальний Авосторонній характер розподілу прав і обов'язків за корпоративним договором;

6) особливості укладення договору - консенсуальні та реальні. Корпоративний договір $€$ консенсуальним, оскільки не передбачає передання майна та вважається укладеним віАтоді, як сторони Аійшло ЗгоАи щоАО його істотних умов;

7) наявність зустрічного надання - безоплатні й оплатні. Корпоративний Аоговір Аля товариств 3 обмеженою та Аодатковою відповідальністю безоплатний, що прямо переАбачено у ст. 7 Закону "Про ТОВ". Закон "Про АТ" не врегульовує цей момент, оАнак через тотожний зміст цих Аоговорів немає причин вважати договір між акціонерами оплатним;

8) залежно віА форми укладення - усні та письмові. Як Закон "Про ТОВ", так і Закон "Про АТ" передбачають, що корпоративний Аоговір уклаАається в письмовій формі.

За результатами Аихотомічної класифікації корпоративний Аоговір є вільним, поіменованим, зАебільшого взаємопогодженим та Авостороннім, консенсуальним, безоплатним, організаційним Аоговором з обов'язковою письмовою формою.

У результаті проведеного аналізу ознак і функцій корпоративного Аоговору, зокрема й тих, що притаманні йому та виділяють його сереА інших, можемо встановити місце такого Аоговору в системі Аоговорів.

Уважаємо за Аоцільне віАнести корпоративний Аоговір Ао цивільно-правових Аоговорів, а не до господарсько-правових. Такий висновок випливає з того, що за господарським Аоговір встановлюються, змінюються або припиняються господарські зобов'язання [7, с. 228-229], а корпоративний Аоговір не $є$ підставою Аля зміни зобов'язань, а лише встановлює порядок реамізації вже наявних [4]. Такої ж позиції у своїх працях Аотримуються А.В. Сіщук і М.М. Сигидин [7, с. 228-229]. 
Висновки з АосліАження та перспективи поАальших розвіАок у цьому напрямі. У піАсумку можемо стверджувати, що разом із загальними ознаками, функціями, які притаманні корпоративному Аоговору як Аоговірній конструкції, йому властиві власні, специфічні функції й ознаки, які тісно пов'язані зі специфічним преАметом такого Аоговору. Аихотомічний піАхіА ао класифікації дозволив виокремити набір власних характеристик корпоративного Аоговору, що теж розкривають його особливу правову природу. Це
АОзволяє виАіляти його місце в системі Аоговорів та говорити про його цивільно-правову природу.

Перспективи подальших АосліАжень. Оскільки корпоративний договір все ще перебуває на етапі свого становлення в законодавчому полі України, його правова природа потребує подальших досліАжень. Зокрема, цінним буде зАійснення спроби оАноступеневої класифікації корпоративного Аоговору, а також більш Аетальне АосліАження питання щодо цивільно-правової суті корпоративного Аоговору.

\section{NITEPATYPA:}

1. Алексашина Ю.Б. Види цивільно-правових договорів як регуляторів цивільних правовідносин. Юридична Україна. 2012. № 12. C. $68-74$.

2. Бігняк О.В. Похідний позов та корпоративний договір як засоби захисту корпоративних прав: досвід України. URL: https:// eppd13.cz/wp-content/uploads/2018/2018-5-3/34.pdf (дата звернення: 24.09.2021).

3. Васильєва В.В. Поняття та ознаки корпоративного договору. Актуальні проблеми вдосконалення чинного законодавства Украӥни. 2018. Вип. 47. С. 52-61.

4. Господарський кодекс України : Закон від 16.01.2003 p. № 436-IV / Верховна Рада України. URL: https://zakon.rada.gov.ua/ laws/show/436-15\#Text (дата звернення: 04.05.2021).

5. Договірне право України. Загальна частина : навчальний посібник / Т.В. Боднар та ін. ; за ред. О.В. Дзери. Київ, 2008.896 с.

6. Комиссарова Е.Г. Формально-логические аспекты понятия «правовая природа». Вестник Пермского университета. C. 24. URL: https://cyberleninka.ru/article/n/formalno-logicheskie-aspekty-ponyatiya-pravovaya-priroda/viewer (дата звернення: 09.09.2021).

7. Корпоративне право України: проблеми теорії та практики : монографія / за заг. ред. В. Васильєвої. Івано-Франківськ, 2017. $612 \mathrm{c}$.

8. Красавчиков О.А. Гражданско-правовой договор: понятие, содержание и функции. Гражданско-правовой договор и его функиии : сборник научных трудов Свердловского юридического института. Свердловск, 1980. С. 3-20.

9. Луць В.В. Контракти в підприємницькій діяльности : навчальний посібник. Київ, 2008. 576 с.

10. Про акціонерні товариства : Закон України від 17.09.200 p.8 № 514-VI / Верховна Рада України. URL: https://zakon.rada.gov. ua/laws/show/514-17/ed20151209\#Техt (дата звернення: 21.05.2020).

11. Про товариства з обмеженою та додатковою відповідальністю : Закон України від 06.02.2018 р. № 2275-VIII / Верховна Рада України. URL: https://zakon.rada.gov.ua/laws/show/2275-19 (дата звернення: 13.06.2021).

12. Рябова К.О. Правова природа корпоративних договорів. Юридичний вісник. Повітряне і космічне право. 2018. № 4. С. 164. URL: http://nbuv.gov.ua/UJRN/Npnau_2018_4_24 (дата звернення: 11.09.2021).

13. Цивільний кодекс України : Закон від 16.01.2003 р. № 435-IV / Верховна Рада України. URL: https://zakon.rada.gov.ua/laws/ show/435-15\#Tеxt (дата звернення: 04.05.2020).

14. Щегуренкова А.С. Правовое регулирование корпоративного договора. Развитие современной науки: тенденци, проблемы, nерспективы : сборник статей I Всероссийской научно-практической конференции. Нижний Новгород, 2018. URL: https:// elibrary.ru/item.asp?id=34898185 (дата звернення: 12.09.2020).

\section{Войчишин Олексій Валентинович}

\section{ЩОАО ПИТАННЯ ПРО ПРАВОВУ ПРИРОАУ КОРПОРАТИВНОГО АОГОВОРУ}

Оскільки корпоративний договір лише нещодавно був закріплений у законодавстві України, у статті зроблена спроба розкриття правової природи цього договору. Визначено стан дослідження проблематики, проаналізовано останні праці та досліАження науковців із Ааного питання.

А^я розкриття правової природи Аоговору необхіАно надати його вичерпну характеристику, розкрити його специфічні риси, з'ясувати місце в системі договорів. З'ясування правової природи договору має велике практичне значення, оскільки дозволяє встановити галузеву приналежність договору, розкрити його загальні та специфічні ознаки і функції, здійснити класифікацію договору. Розкриття правової природи договору здатне спростити його застосування на практиці та сприяти послідовній правозастосовній практиці.

Спираючись на попередні дослідження науковців та враховуючи новели законодавчого регулювання, установлено ознаки корпоративного договору. Обґрунтовано, що поряд із загальними ознаками, що притаманні корпоративному Аоговору як Аоговірній конструкцій, він має і специфічні, як-от особливий предмет Аоговору і акцесорність його зобов'язань щодо статутних документів товариств з обмеженою віАповіАальністю, товариств 3 Аодатковою відповіАальністю й акціонерних товариств. Саме наявність спеціальних ознак є ключовим критерієм Аля віАмежування корпоративного договору віА суміжних за своєю природою Аоговорів, наприклаА його розмежування із засновницьким договором. Окрім цього, запропоновано похідні специфічні ознаки.

У статті також дослілжено функції корпоративного Аоговору. Ао загальних функцій цього Аоговору можна віАнести гарантійну, регулятивну й охоронну функції. Запропоновано й обгрунтовано специфічні функції корпоратив- 
ного договору (напрями його впливу на суспільні відносини), а саме: майнову функцію, управлінську функцію, прогностичну функцію та функцію контролю.

Також зАійснена спроба класифікувати корпоративний договір за дихотомічними критеріями. Установлено, що корпоративний договір є вільним, поіменованим, здебільшого взаємопогодженим та Авостороннім, консенсуальним, безоплатним, організаційним Аоговором, що вчиняється в обов'язковій письмовій формі.

Окрім того, у статті аргументується, чому за своєю правовою природою корпоративний Аоговір більше тяжіє Ао групи цивільно-правових Аоговорів, ніж Ао господарсько-правових Аоговорів.

КАючові слова: корпоративне право, корпоративний договір, правова природа, акціонерні товариства, товариства з обмеженою віАповіАальністю.

\section{Voichyshyn Oleksii}

\section{REGARDING THE LEGAL NATURE OF THE SHAREHOLDERS' AGREEMENTS}

Since the shareholders' agreement was not so long ago enshrined in the legislation of Ukraine, the article attempts to disclose the legal nature of this agreement. The current state of research on the problem is determined and the latest works and research of scientists on this issue are analyzed.

The disclosure of the legal nature of the agreement requires the necessity to provide a comprehensive description of the agreement, disclose its specific features and establish a place in the system of contracts. Clarification of the legal nature of the agreement has a great practical importance, as it allows to establish the sectoral affiliation of the agreement, disclose its general and specific features and functions, and classify the agreement. Disclosure of the legal nature of the shareholders ' agreement can simplify its application in practice and promote consistent law practice.

Based on scientists' previous research and considering the novelties of legislative regulation, the characteristic features of shareholders' agreements have been established. In particular, it is substantiated that along with the general features that belong to shareholders agreements as a contractual structure. It also has specific features such as the special subject of the agreement and the accessory nature of its obligations to statutory documents of limited liability companies, additional liability companies and joint-stock companies. Special features are key to distinguishing a shareholders' agreement from related agreements, such as its separation from the memorandum of association. In addition, specific derivative features are proposed.

The article also explores the functions of shareholders' agreements. The general functions of this agreement include warranty, regulatory and security functions. The specific functions of shareholders' agreements (directions of its influence on public relations) are offered and substantiated, namely: property function, managerial function, prognostic function, and control function.

Also, it was made an attempt to classify shareholders' agreements according to dichotomous criteria. It is established that a shareholders' agreements are a free, named, mostly mutually agreed and bilateral, consensual, free of charge, organizational agreement, which is made in a mandatory written form.

In addition, the article argues why, by its legal nature, a corporate agreement tends more to a group of civil law agreements than to economic law agreements.

Key words: shareholders' agreement, limited liability company, corporate rights, charter, essential terms of the agreement, corporate law. 